\title{
ARCHITECTURAL CONSERVATION AS A PROMOTER OF CULTURAL IDENTITY
}

\author{
Kamini Sinha \\ Department of Architecture, National Institute of Technology, Patna, India
}

\begin{abstract}
Culture has been generally understood as the characteristics and knowledge of a particular group of people in the areas encompassing language, religion, cuisine, social habits, music and arts. Margaret Mead, an American cultural anthropologist defined Culture as "the whole complex of traditional behaviour which has been developed by the human race and is successively learned by each generation". Such shared patterns on behaviour are largely influenced by the nature of spaces. Since architecture is the physical manifestation of culture, any change in the same has the power to gradually bring about a change in culture. Societies which have been closely knit have grown to be non-concerned of each other with changing design patterns. External influences on architecture and planning from different sources has been modulating the culture of places. And so, a conscious action towards conservation of culture can be strengthened by conservation of local architectural heritage. This important fact has been established in this paper through the study of urban planning and designs case studies through history of the city of Patna, Bihar, India. With the assumption that architecture is a complete symbol of human culture it tries to study the role of architectural conservation in promoting cultural identity.
\end{abstract}

Keywords: culture; architecture; planning,; external influence;, architectural conservation.

Cite this Article: Kamini Sinha, Architectural Conservation as a Promoter of Cultural Identity, International Journal of Advanced Research in Engineering and Technology, 10 (5), 2019, pp 22-37.

http://iaeme.com/Home/issue/IJARET?Volume $=10 \&$ Issue $=5$

\section{INTRODUCTION}

Conservation of Architectural Heritage has innumerable significance for the society. It helps conserve resources and knowledge systems. As defined by Diane Switzer, Vancouver Heritage Foundation, Conservation today is less about preserving precious places as museums and more about preserving the sense of character, unique identity and history of communities where people live, works and recreate [1]. In other words, comprehensive Conservation of any settlement can help conserve the culture of the place. This can be understood well if the fact that a change in architectural style, design and planning gradually changes the culture can be explained. This paper explains the same through review of the growth of the city of Patna, Bihar, India.

The historic city of Patna is a continuously living place of nearly three millennia. Architecture is one of the most important symptom and characteristic of its different historic 
periods. Urban development is governed by the social, political and especially cultural processes i.e. the physical and spatial arrangements characterising urban development i.e. the entire man-made environment are unique products of a particular society and culture, operating within a given distribution of power [2]. The present Patna encompasses of a large variety of architectural heritage inclusive of its indigenous style, architecture developed under the influence of various external sources including Mughal, European, Bengal and lately the global influence. These various sources of influence have played their own roles in altering the architecture and planning of the city resulting in a gradual change in the culture of the place.

\section{GROWTH OF THE CITY OF PATNA}

Patna, the capital of present Bihar, a linear city on the south bank of the Ganges, has been living through nearly three millennia; [Fig [1],. This has been researched and corroborated through archaeological findings, travelogues of travellers like Megasthenes who visited Patliputra (historic name of Patna) in $4^{\text {th }}$ century B.C, Fahien who visited in $4^{\text {th }}$ century A.D and Huang Sang who Visited India in $7^{\text {th }}$ Century A.D and also religious texts of Buddhism and Jainism [3]. The city has been in existence since much before $6^{\text {th }}$ century B.C and continued to live through centuries till present time. It has had different phases of growth through the said long period.

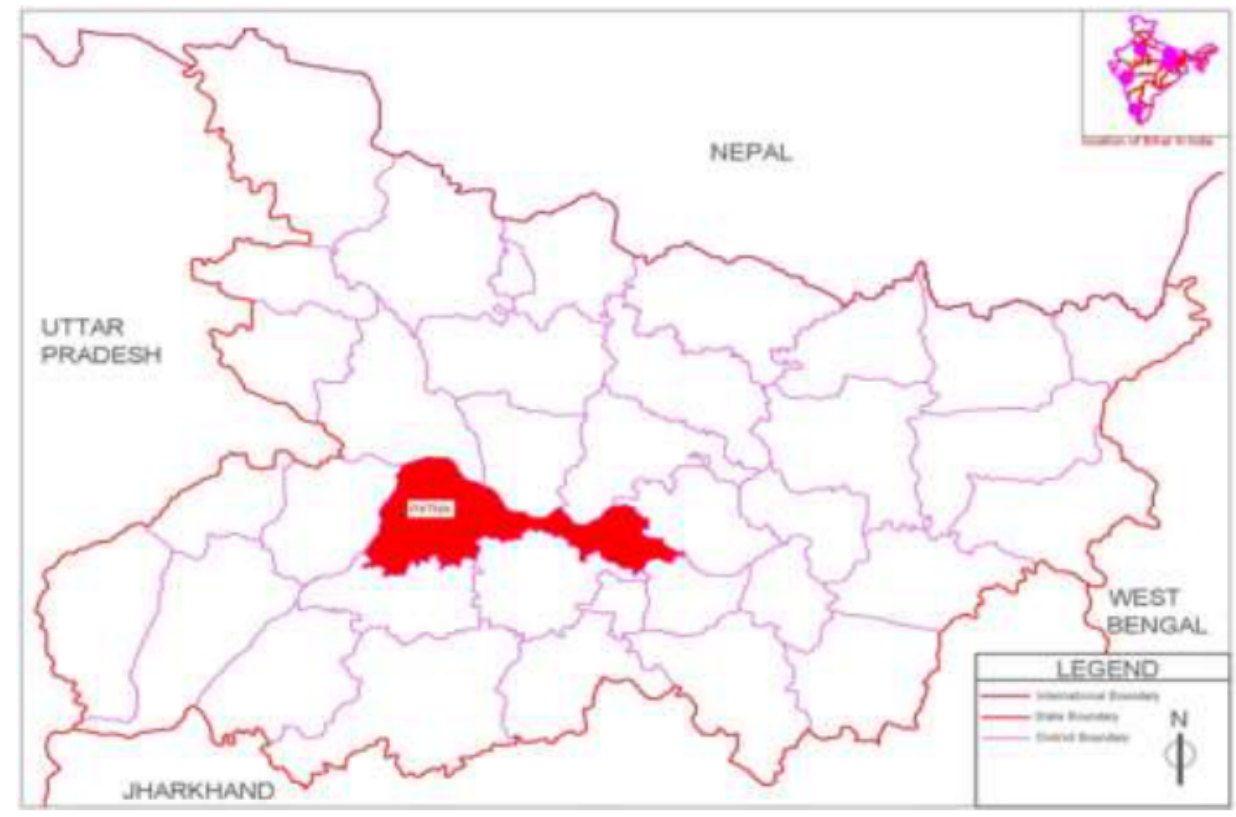

Figure 1 Map of Bihar

Based on archaeological findings, it has been established that the ancient capital of Patliputra of the Nanda dynasty (345-321 B.C), Mauryan dynasty (322- 180 B.C) and Sunga dynasties (185 -73B.C) developed and grew in this very location on the banks of the Ganges; Fig [2] 


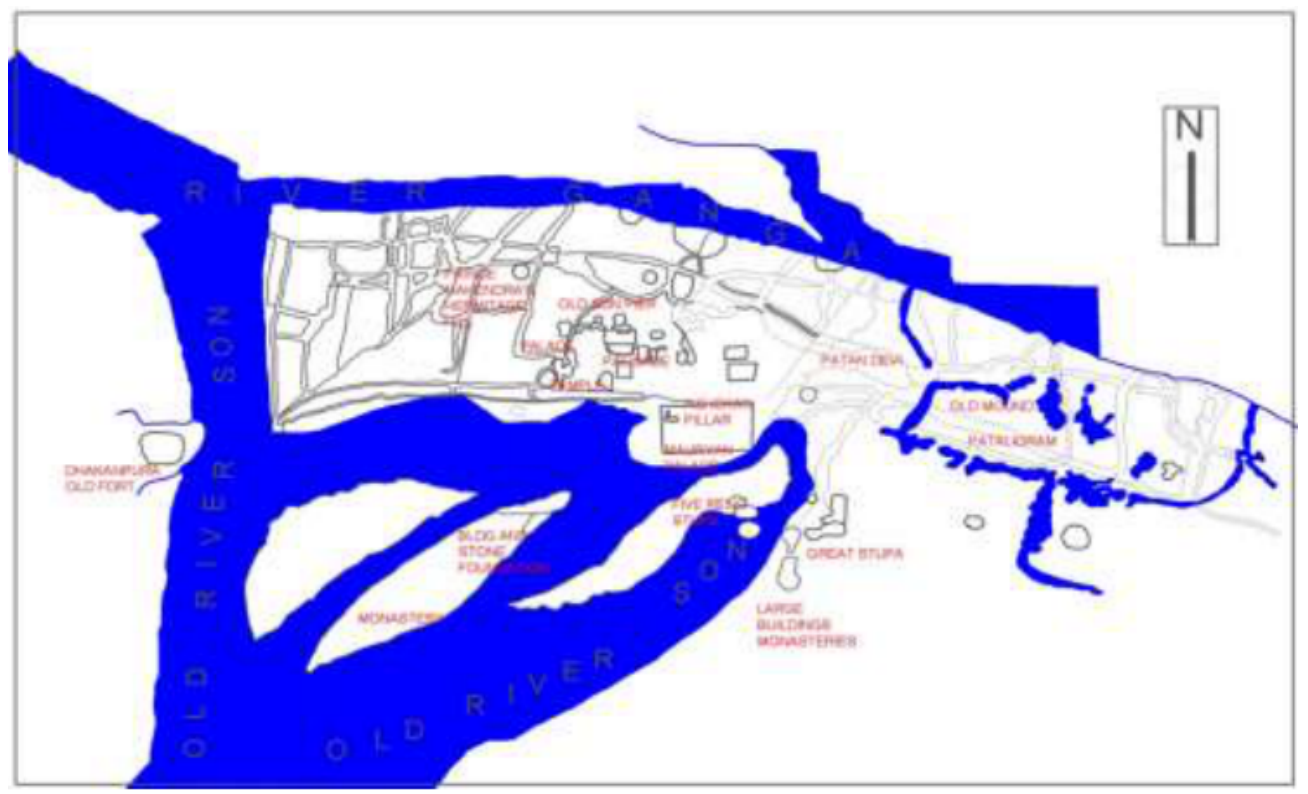

Figure 2 Ruins of Patliputra, Wandell's Map, Master Plan 1961

When the capital was shifted to Ujjain under the Gupta dynasty [4], Patliputra slowly lost its importance and the settlement shrunk to the nature of a small village on the bank of the Ganges.

It re-found its importance when the afghan ruler Sher Shah Suri discovered the strength of the site and established his fort on this location in early sixteenth century. He fortified the city containing the existing population within it. The untimely death of Sher shah in 1545 and of his son in 1553 ended the great period of the rule of the Surs. Bihar was for the first time organized into a separate province of the Mughal emperor Ziauluddin Mohammad Akbar's empire in 1575 [5]. Bihar about this time was virtually in the hands of a number of military commanders and fief holders. With the new importance given to the province by the administration and Patna being the provincial capital, muslim population in the city started growing and their residences and religious structures started dotting the city. With passage of time, the city became densely populated and it finally spilled out of the fortified area both to its east and west. To the west of the existing city were developed the baghs(orchards) and the summer palaces of the nawabs (Landlords).

It was in the beginning of the seventeenth century that the European East India companies started coming to Patna for trading. The Portuguese were the first. They were followed by the English and the Dutch. And then finally the French and the Danes made their way to Patna [6]. All of them came for trading and the chief items of trade were cloth, opium and saltpetre and later indigo.

Even when the city was contained within the city walls, these trading companies had their business settlement outside the city walls, since they did not want much intrusion from the local administrators and also to avoid conflicts with the local public; Fig [3 ] 


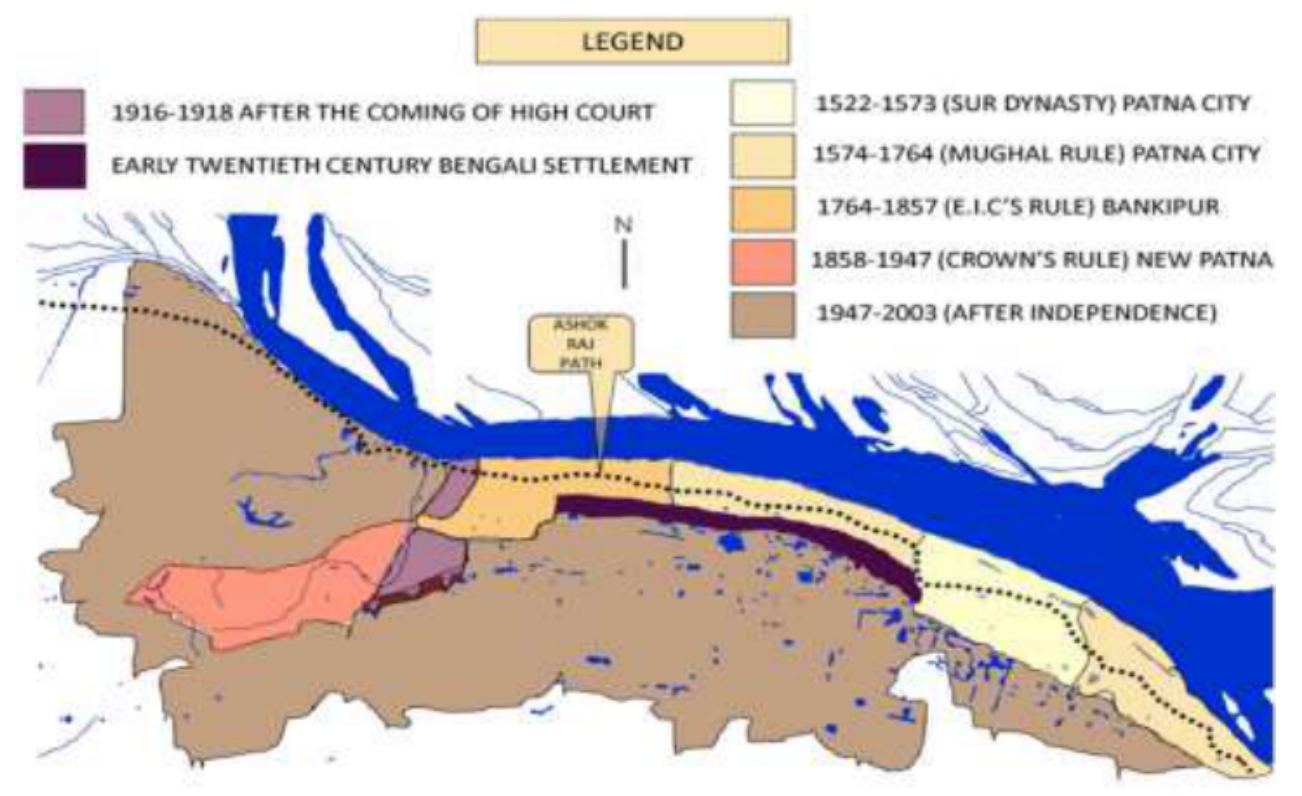

Figure 3 Growth of Patna in stages

During that period, the business settlements were the only place occupied by the Europeans and the few residences that they had in Patna, were either inside the campus of their business structure or just around them. English company had its factory just outside the western gate of the city; Fig [4] Dutch godown was further west and Danish establishment just outside the eastern city gate.

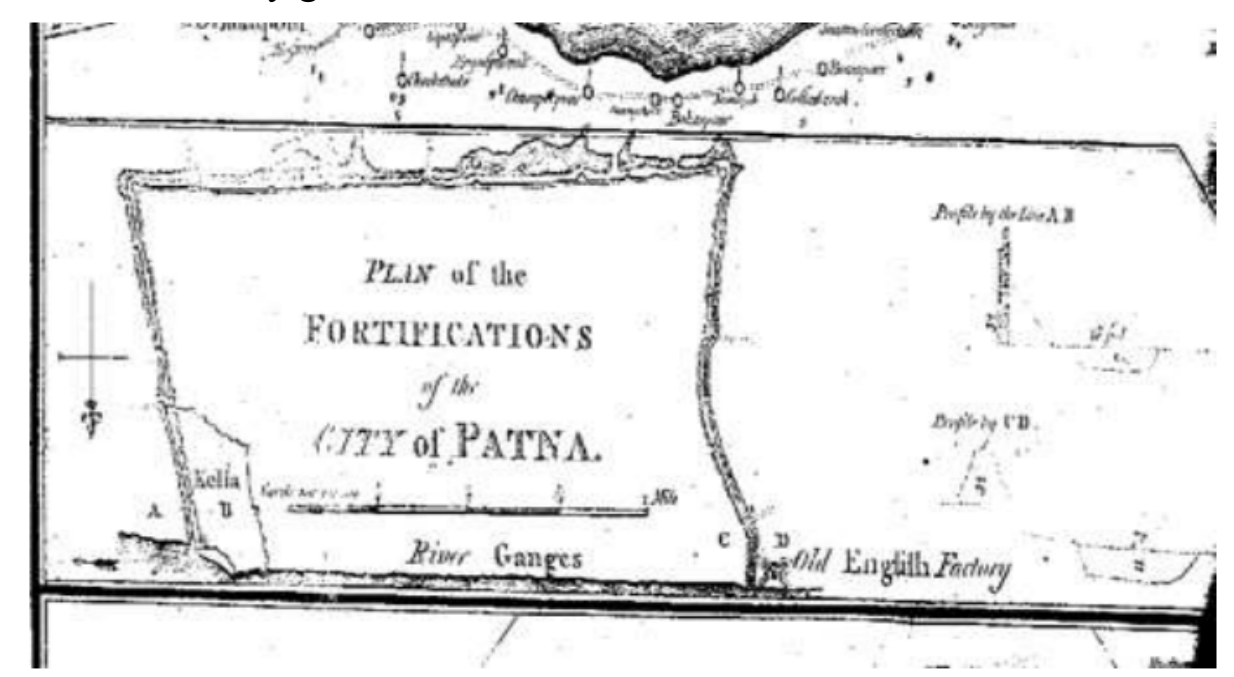

Figure 4 Wall Map of Patna City Municipality, Surveyed in season 1932-33 under Bihar and Orissa Act I of 1920,

Sourced at National Archives, New Delhi

After the East India Company got political control in 1764, the number of Europeans started growing in the city. The physical shape changed because the growing English population did not want to live in the old city. They desired to maintain their distance from the local people. They disliked living in the old city which was congested and chances of clash with the local population were more. As such they settled in an area outside the old city. Since the area just west of the city was already occupied by the pleasure gardens, they moved further west to occupy the area, which is presently known as Bankipore. [4] 
The old city of Patna thus started growing in length. (The city, which was just three miles long when the English had first come, became nine miles long, when Francais Buchanan came to survey it in 1812.) This growing settlement, like the old city, grew on both side of the main road parallel to the Ganges. The bank of the Ganges got dotted by the bungalows of the Europeans. In 1857, the administration of India passed from the hands of the British East India Company into the hands of the British crown. The decision was taken at the Delhi durbar in 1911, to unite the states of Bihar and Orissa under a new lieutenant governorship with a legislative council and Patna as its capital. The site chosen for developing new Patna complete with all administrative structures was towards the south west of Bankipore.

With the High court being built in 1916-1918, the area between Bankipore and New Patna got filled up with the Bungalows of High court judges. This was also the time when lots of educated Bengalis shifted to Patna to work either in the judiciary or education system which also had got an impetus with setting up of Patna University in early twentieth century. Most of these settled and had their residences in the area south of Ashok Rajpath along the length between Old city and Bankipore.

India gained independence in 1947 and the first Master Plan was formulated and published in 1962. Planned colonies were proposed in areas extending towards south part of the existing city. The city kept growing southwards to the existing length being finally limited by River Son flowing in from the south. Since the available width between the two rivers got fully built, the city kept growing in length which is still the pattern of evolution.

\subsection{Local Residential Architecture and town planning of Patna}

\subsubsection{Indigenous Residential Architecture in the old city (Historic Core hereafter referred to as Patna City)}

The present city of Patna, during its long period of existence has accumulated various types of residential architecture. The earliest local residential architecture, which is still extant in Patna city, is the courtyard houses with introvert planning;

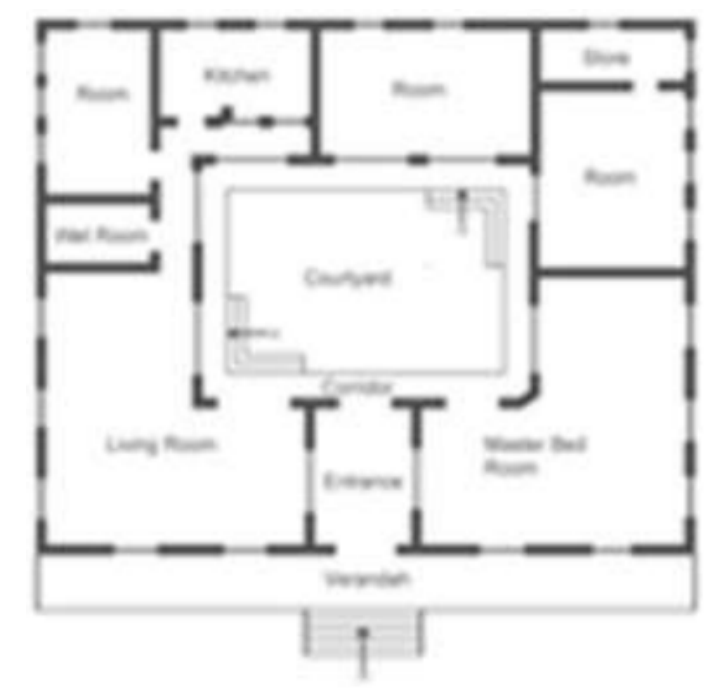

Figure 5 Basic Layout of Courtyard House

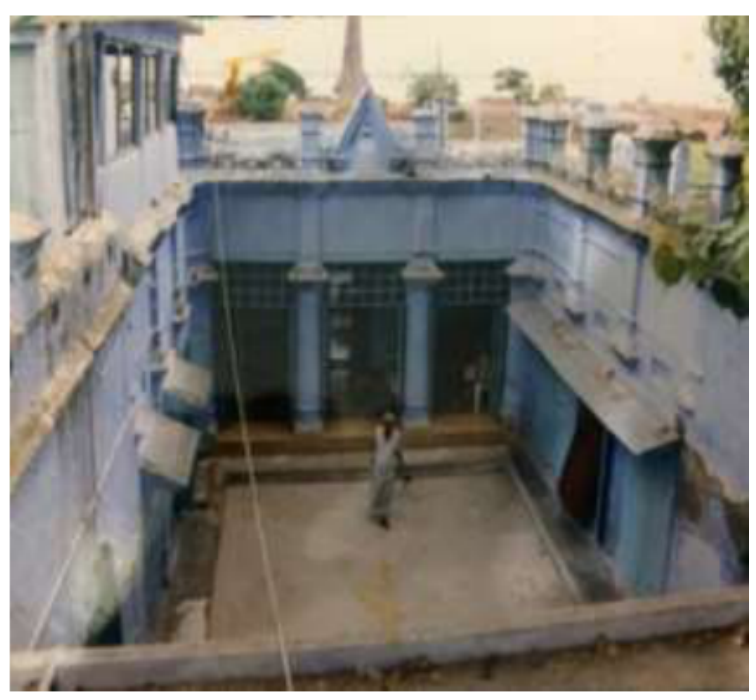

Figure 6 View of a Courtyard House

The courtyard is the central part of the house surrounded by a verandah on which opens all the rooms of the house. One of the rooms, which is placed towards the front of the house has the main entrance door opening on a verandah which may or may not be covered. This is the basic layout for residences of all strata of the society. The economic condition of the family has an effect on the size of the spaces, number of rooms, finishes adopted, dimension 
of the corridor/verandah, types of openings and detailing. Whereas for the richer class everything is elaborated and even majestic at times, the less rich families to poor families restrict the layout to being majorly utilitarian in nature.

The culture of the Hindu society had the motto "Ateethe Devo Bhava" which means Guests are equivalent to god and so there is openness at the entrance for the God to enter. The guests are given a warm welcome and are seated on the verandah which functions as a sit out for the male members of the family and at times includes the senior aged female members as well. This open verandah facing the street doubles as resting places for anyone and everyone in the area who needs a resting place during rains or the heated afternoons of summers. There are no restrictions to the usage of such verandah. This is the warm culture of the society and at times these passer byes are even offered cold water/ food or drinks by the residents of the house. This culture shows that crime was not common in the city. These verandas also served as points from where the elders of the house kept an eye on the children playing in the street, the toddlers playing on the verandah itself or any incident happening in the street and thus can be termed as a watch point. During nights, male members even used these entrance verandas for sleeping. These can be termed as private to semi-public areas of the neighbourhood where get-together and evening meetings were also conducted.

The Muslim culture includes purdah system for the females, so, their residences are comparatively introverted in design. Even in the courtyard houses, the men were generally restricted to the front of the house while the females were accommodated in the inner section. The entrance had an introvert planning which restricted entrance without permission.

The courtyards were the major activity area of the residence where the female members of the family assembled for the day's activities. It is their family area where all activity like cooking, cleaning, kid's care, socialising etc. would be carried out. All family functions were also carried out in these courtyards.

Since Patna is a river town developed linearly along the southern banks of the Ganges, and also, because the mode of transport before the coming of railways in 1866 was waterways, the city was greatly oriented towards the river. The houses of the wealthy were generally built along the bank of the Ganges and these houses, apart from the courtyard, have two very important features incorporated in their design. The first is the windows / Jharokhas / balconies /sit outs projecting into the river or facing the river. These give a nice view of the river to the residents and also channelize the gentle river breeze into the living areas giving a very pleasant living condition in the interior of the houses. The second characteristic is the private / public ghats or open / concealed stairways leading into the river, used for bathing or served as passage to the boats/steamers anchored on to the river bank/ ghat. The river played a very important role in the city's life; 


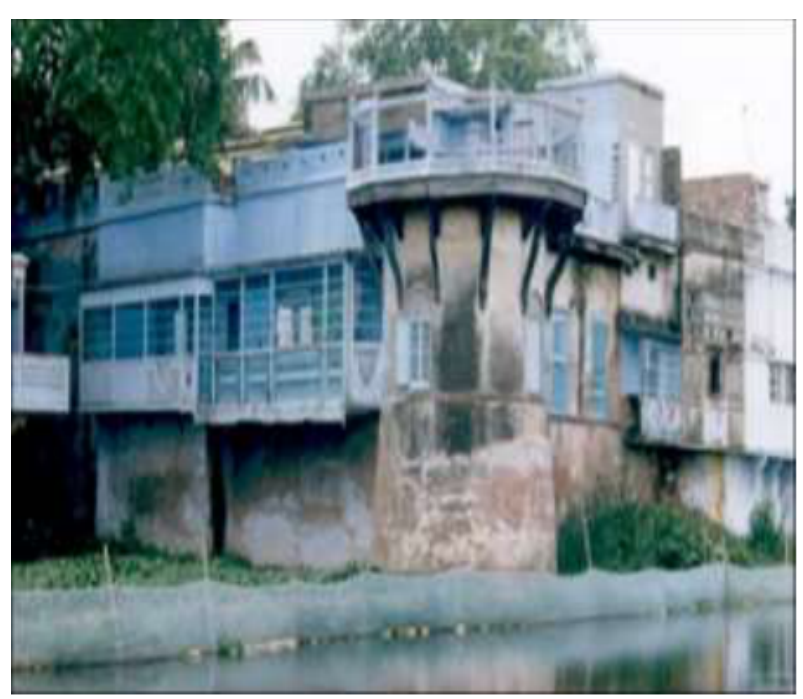

Figure 7 Viewpoints or Jharokhas incorporate

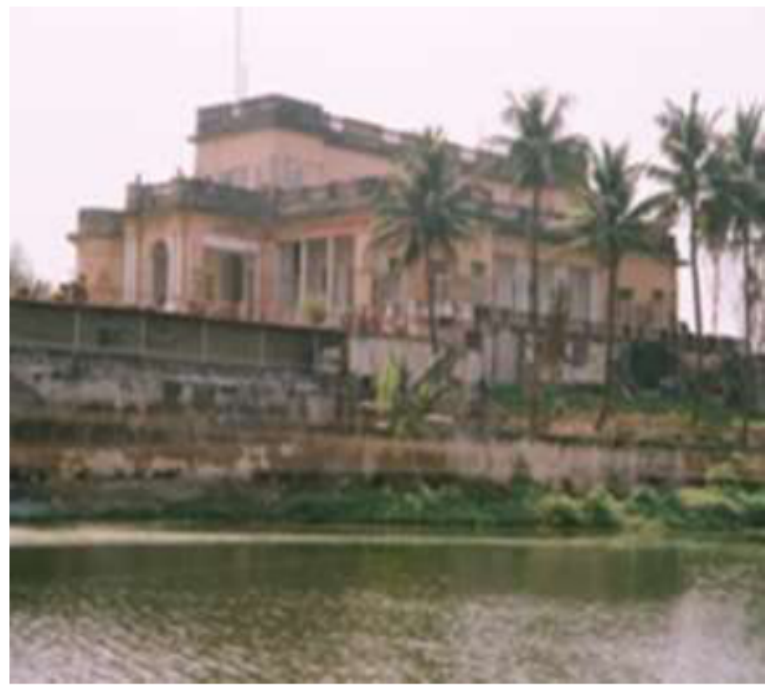

Figure 8 Residence addressing the river

\subsection{Town Planning of Patna City}

Patna was always a centre of trade and commerce. It had its major market areas towards its east end. The city is organised into mohallas / wards which was broadly divided on community basis [5]. The houses are very closely built and the streets are narrow. The main road of the city named Ashok Rajpath runs east to west with two main gateways "Paschim Darwaza" (Western Gate) and "Purab darwaza" (Eastern Gate) placed at west and east end of the fortified city respectively. This main road is joined by internal roads from north and south, which are comparatively narrow and lead into the mohallas. The city is spotted with the religious structures of both hindu and muslim communities. With passage of time the historic city became densely built

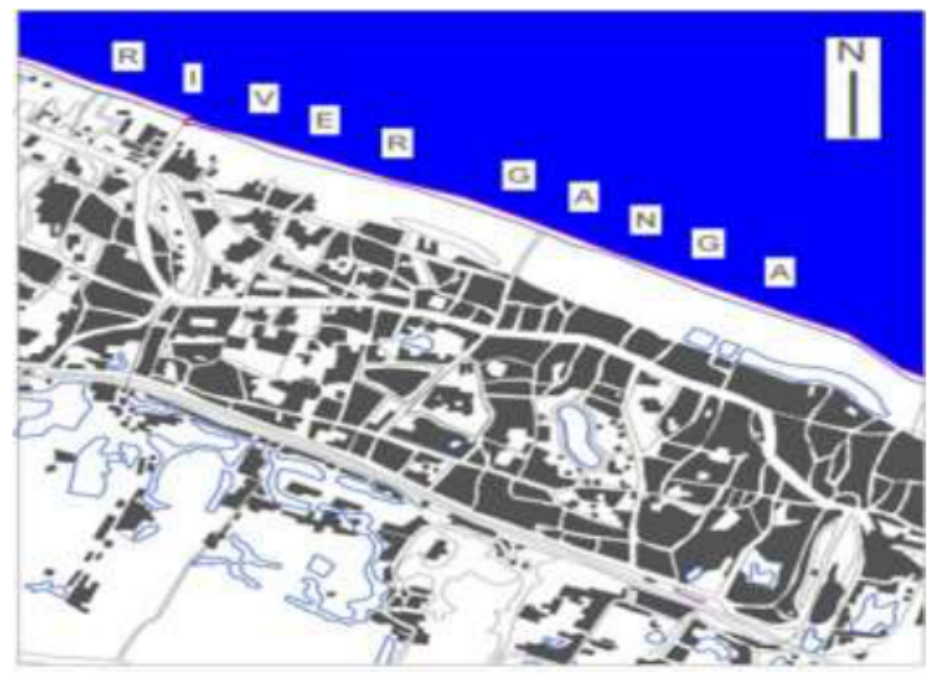

Figure 9 Map of Patna City

\subsection{Residences of the Europeans in and around Patna City}

The Europeans started coming to the city in early seventeenth century. The earliest extant European residential architecture in the city has been built by the Dutch East India Company, built midway between Patna city and Bankipore area. This structure was built in the midseventeenth century to function as their opium godown cum residence; Fig [10], Fig [11] 


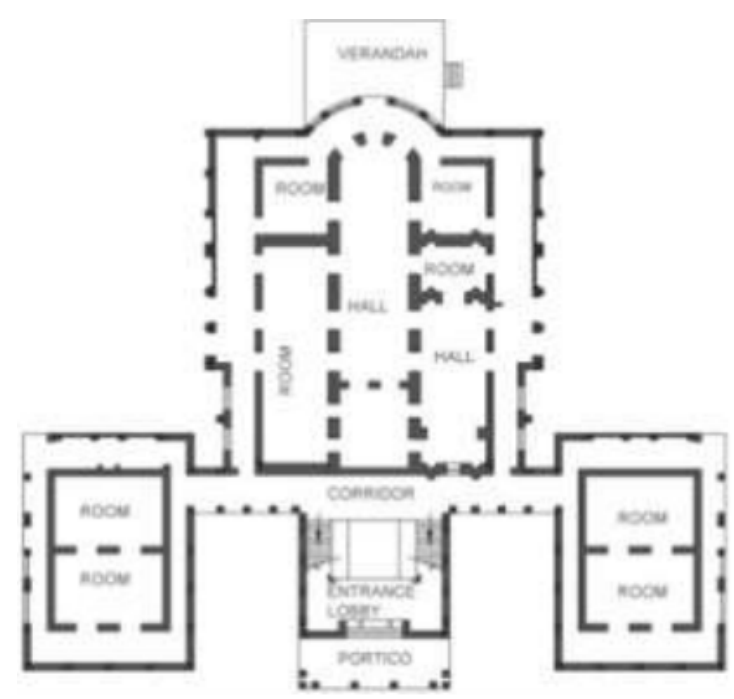

Figure 10 Plan of the Dutch Structure

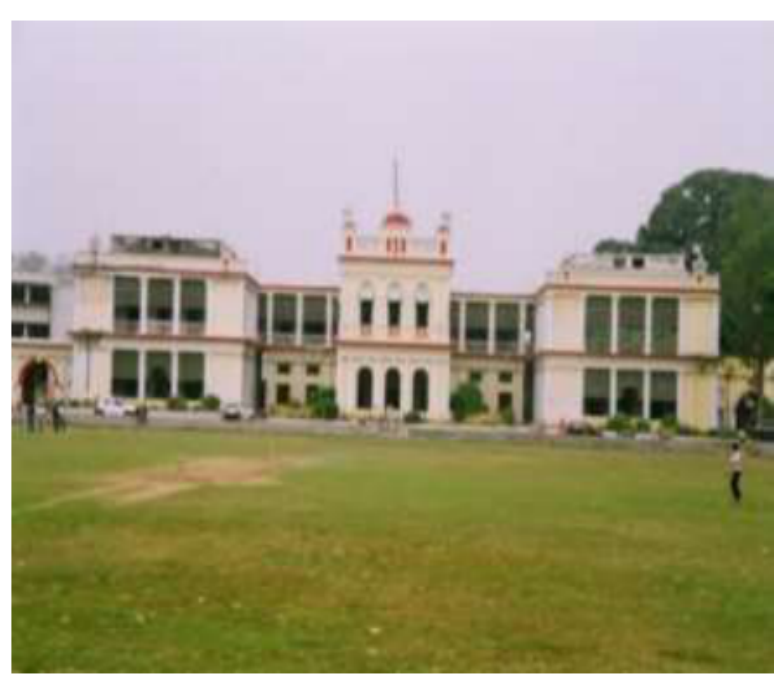

Figure 11 Dutch Structure in Patna

The depth of the structure equals its width. The plan has three wings and the central wing is deeper than the other two. The central wing has a huge hall in the centre which is circular at the rear end and opens on to a large platform, towards the Ganges. This platform was used as a loading platform.

The room just south of this hall has an in-built fire place in the south wall and the large rectangular room to its east displays beautiful detailing. The north and south walls of the room have semi-circular niches in the wall which probably were designed to hold idols. All the four walls have beautiful stucco work on them. This probably served as their drawing room.

The entrance lobby to the south has a huge wooden staircase leading to the first floor. It has long verandas on all the four sides which have ionic columns on the ground floor and Corinthian column on the first floor. The portico has semi-circular arches between the columns and the top of the structure is decorated with pinnacles.

This structure brought a totally new style of architecture which started changing the skyline of the city.

The Danes had also built a residential structure to the east of Purab Darwaza. It was built in late eighteenth century, approximately in 1770s

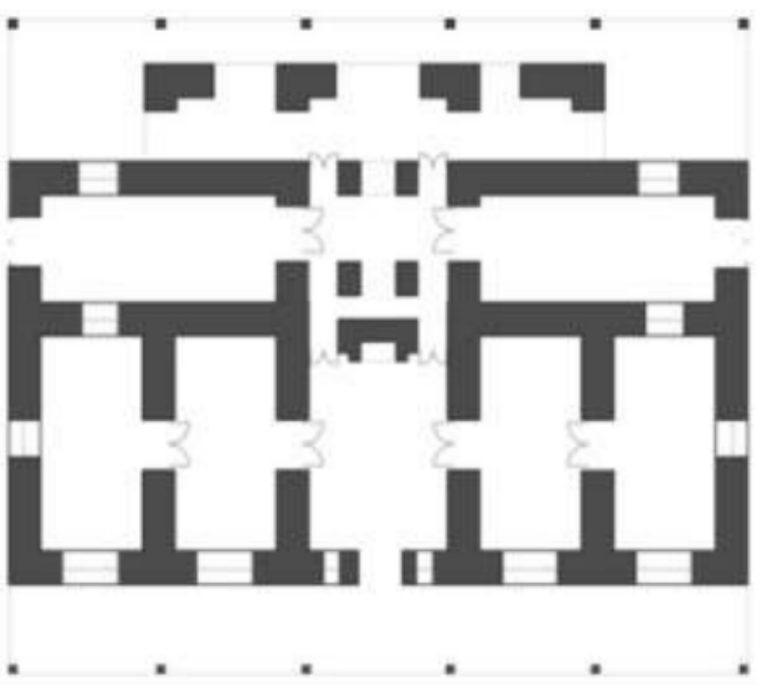

Figure 12 Plan of the Danish Residence

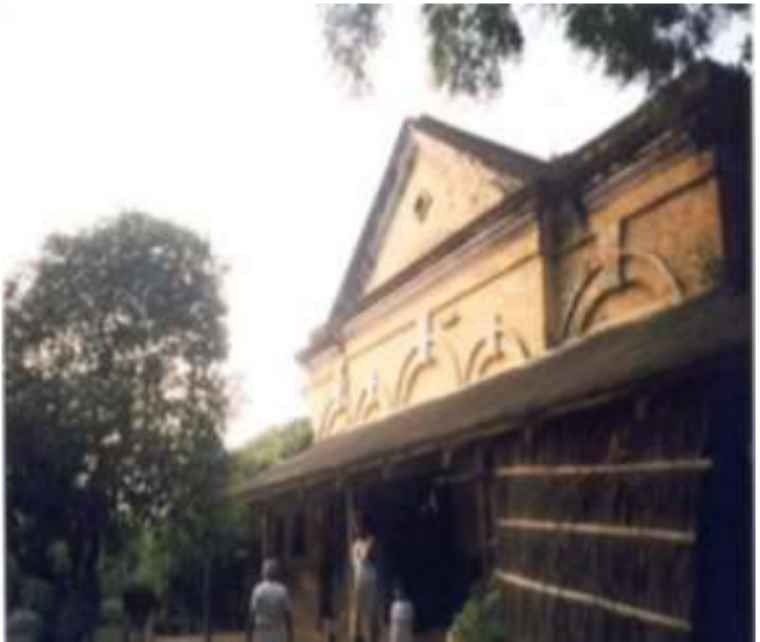

Figure 13 Danish Residence 
The plan of the structure is in the form of a cross with wide verandah on the front and the rear. The house is well-ventilated with lots of openings on all the sides. It has a lean to roof over the front verandah functioning like a long projecting eave over the openings; the front has blind arches with emphasized key-stones. This treatment to the wall surface is continued on all sides of the house. The rooms have barrel vaulted roof, while a pediment stands over the centre of the front face. This was yet another style of architecture which was new to the city.

The English East India Company built its residence cum godown inside their fortified structure just outside the Paschim Darwaza on the bank of the river. The residence of the factory super-in-tendent was situated on the first floor of the same structure.

The rooms are dark with lack of openings in the walls. Centrally located is a stair well which (as per oral history) links the structure through a tunnel to the other side of the Ganges. One tunnel through it also links to the water level of a well situated in the rear courtyard of the structure.

The first floor of the structure occupies half of the built up area and served as a residence in the early days for the factory Superintendent. Though it is simple in all other aspects, it has a well-designed fireplace which was an integral part of European life style. The structure is very simple, devoid of any type of external decoration.

All these European structures brought to the city a different architectural vocabulary. The residences were very compact and maintained distance from its neighbouring structures which was a complete contrast to the Indian counterparts.

Architecture in Bankipore

The residences in this European part of the city were built around an open space and were typically English in style. They were bungalows where the residence stood in the centre of large plots. Large gardens, wide driveways, outhouses for servants, garages or stable for horses, deep verandah in front and rear side and sometimes all around the house, large English windows, double shutters, one with louvers and the other with partial or full glazing, roof generally at two levels, higher for living areas and lower over passages, verandah and corridors thus letting provide clerestory windows to help move out hot air keeping the inner areas cool, compact planning were some of the common characteristics of these bungalows.; Fig [14], Fig [15]

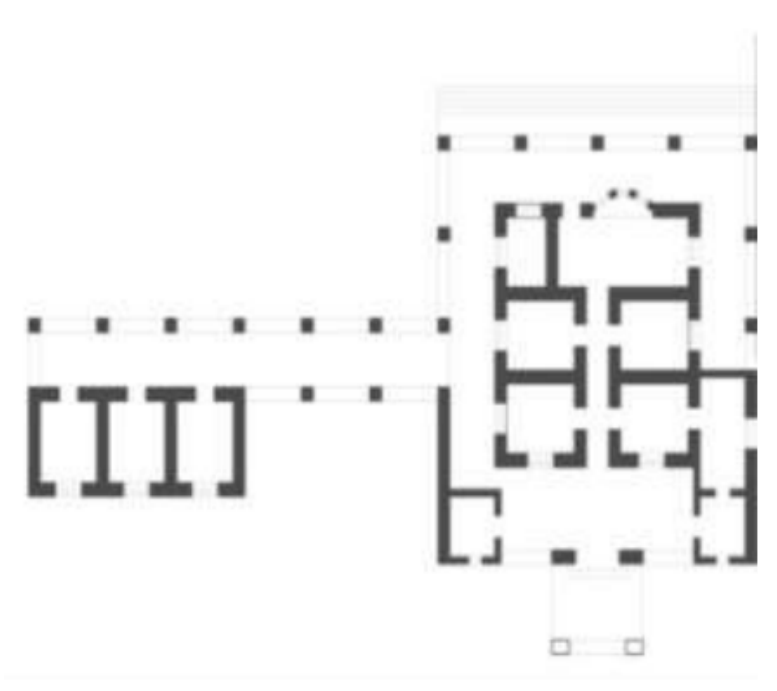

Figure 14 Plan of European Bungalow

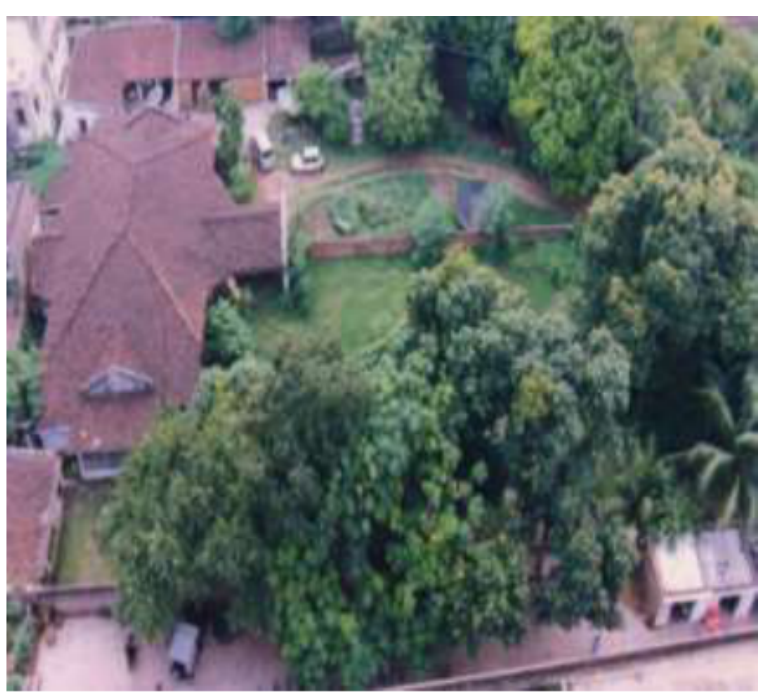

Figure 15 European Bungalow 


\subsection{Town Planning of Bankipore}

Bankipore had a large central open space which was their golf course later referred to as the 'Lawn'. The residences were built all around it. The planning of this area was very open and spacious in contrast to the old city. The residences, church and offices were located around the golf course. It had wide well defined roads and the density of the area was quiet less in comparison to the densely built old city. ; Fig [16]

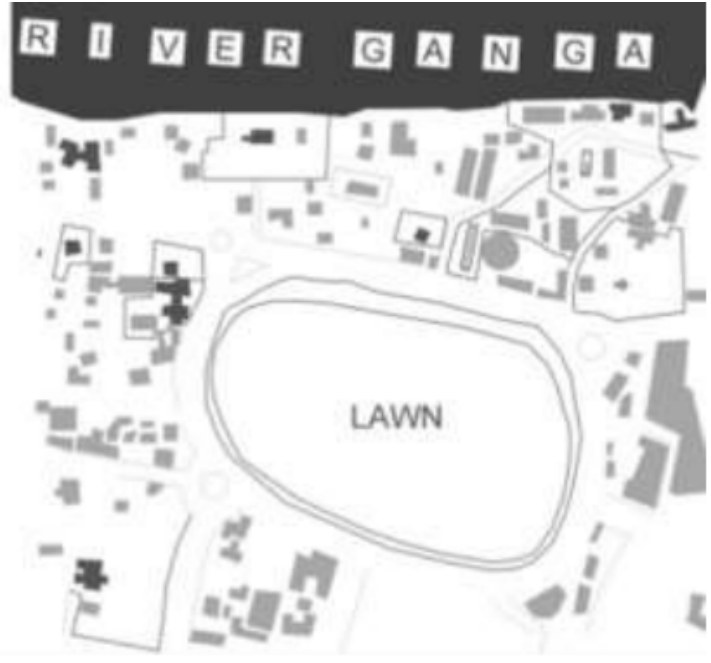

Figure 16 Map of Bankipur

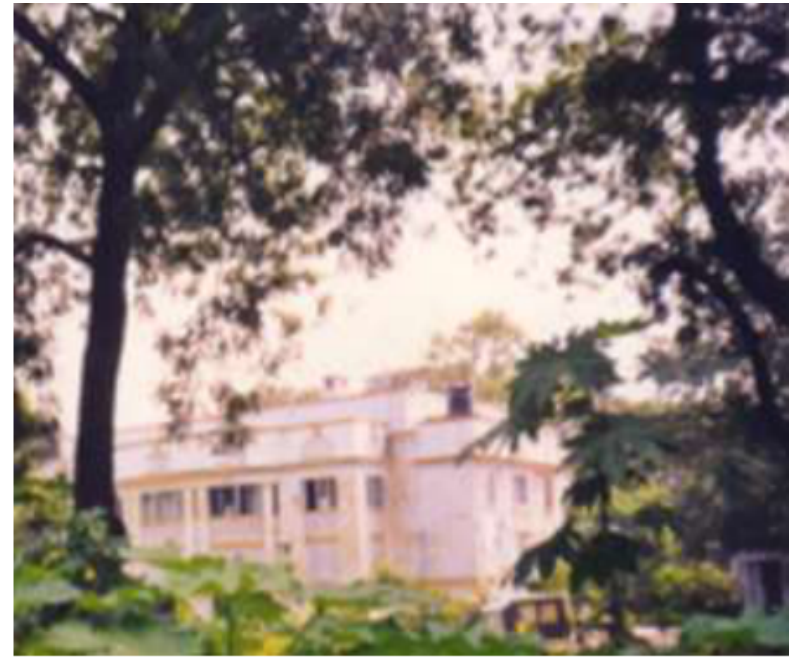

Figure 17 Official Residences in New Patna

The residential component in New Patna was of two types: Government bungalow for administrators and quarters for the officers. The bungalows for the administrators were similar in many aspects to the bungalows at Bankipore but their scale was comparatively grander and the difference being that these were double storied. The officers' quarters were all well planned, laid on grid plan, compact flats, double storied, a cluster of four units in each set having two flats on each floor with open area surrounding them within the campus.

Residential Architecture in New Patna

The residential architecture in new Patna comprised of the official residences ranging from that for the governor, administrators, beaurocrats to government officials. The governor house is a symbol of power in a monumental scale while the residential quarters were an extension of the residential style in Bankipore. The residences of the administrators were bungalow style where the structure was placed in the centre of large plots. The design is compact while the structures are large befitting the status of the administrators. Similar compact residences in apartment style, four units together in a double storied structure were built for the officials but at smaller scale.

\subsection{Planning of New Patna}

The site chosen to develop the new administrative capital, later known as the New Patna, was towards south west of the existing city. It was a one-time planning on urban scale with all its important components - Governor House, Secretariat, Assembly and Council building, High Court, other administrative offices and residences for the officers and staffs.

The work started in 1912 and the main components were completed in 1918. It consists of an axis-a mile long avenue (once named for King George V), focusing on the government house on one end and the Secretariat at the other end. The Council Chamber (1920) is off to one side. The other major component of the new capital area was the High Court building completed in 1916, a little east of the administrative centre. Apart from these offices, the other 
important components were the bungalow of the administrators and the quarters of the staff. This area worked in unison with the Bankipore area as it did not have any market, club or institution of its own. The Government house had huge land attached to it, which was the garden for their botanical research in Patna and to the east end of this, was developed one of an important component of their social life i.e the golf ground. Fig[18]

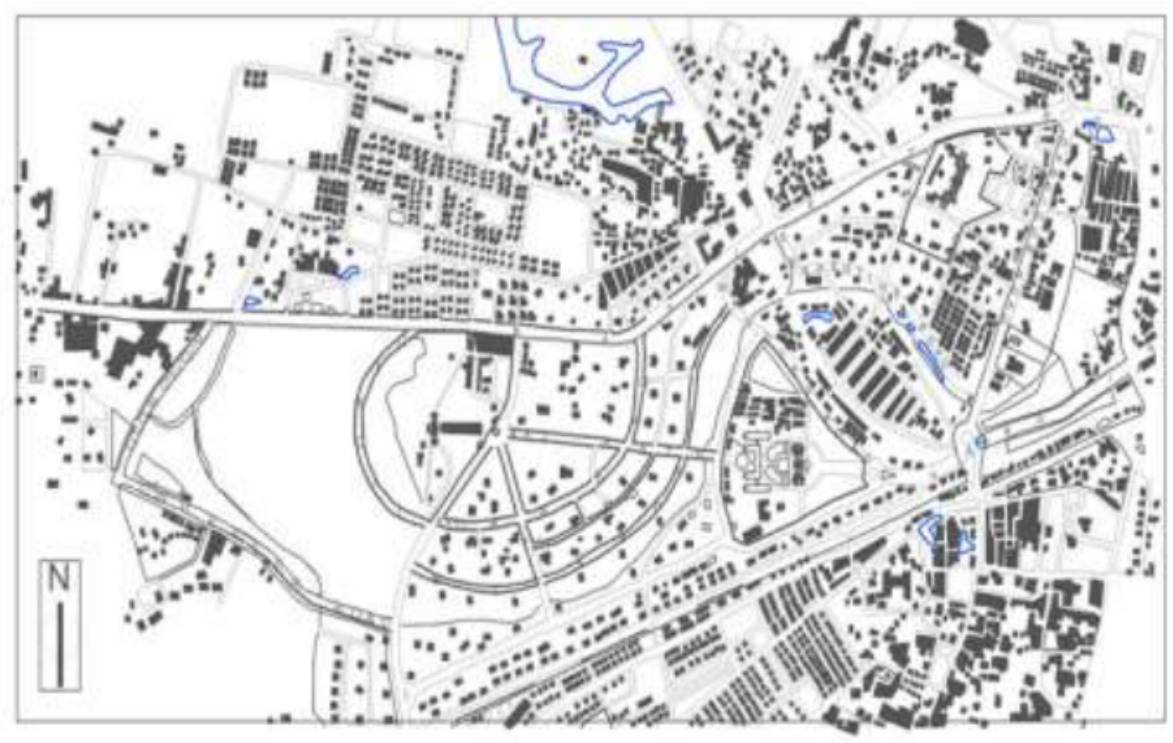

Figure 18 Map of New Patna

\subsection{Architecture of the area linking Bankipore to New Patna}

When the high court was established in Patna, population connected to the legal system settled in the area west to it. This incorporated of the lawyers, barristers, judges and staffs working in the High Court. The private residences of the rich barristers came up all along the Fraser road which ran south from Gandhi Maidan straight to Railway station and Gardiner road which ran parallel to it. This was the area which saw few of the magnificent architecture coming up in the city. All these houses were influenced by the European architecture which the owners saw in other parts of India or abroad when they went to Europe for studying law.

Some of the buildings are: Hassan Manzil built in 1904 which was a house belonging to Mr Hassan Imam, a leading Barrister of Patna, employing gothic arches for its elevation.

'Rizwan' belonging to Mr. Ali Imam, another leading barrister and the brother of Mr. Hassan Imam was built in 1900. It resembles a Scottish castle with a compact planning. The elevation has stone panelling while there are towers at the four corners. It employs gothic arches for its openings. 


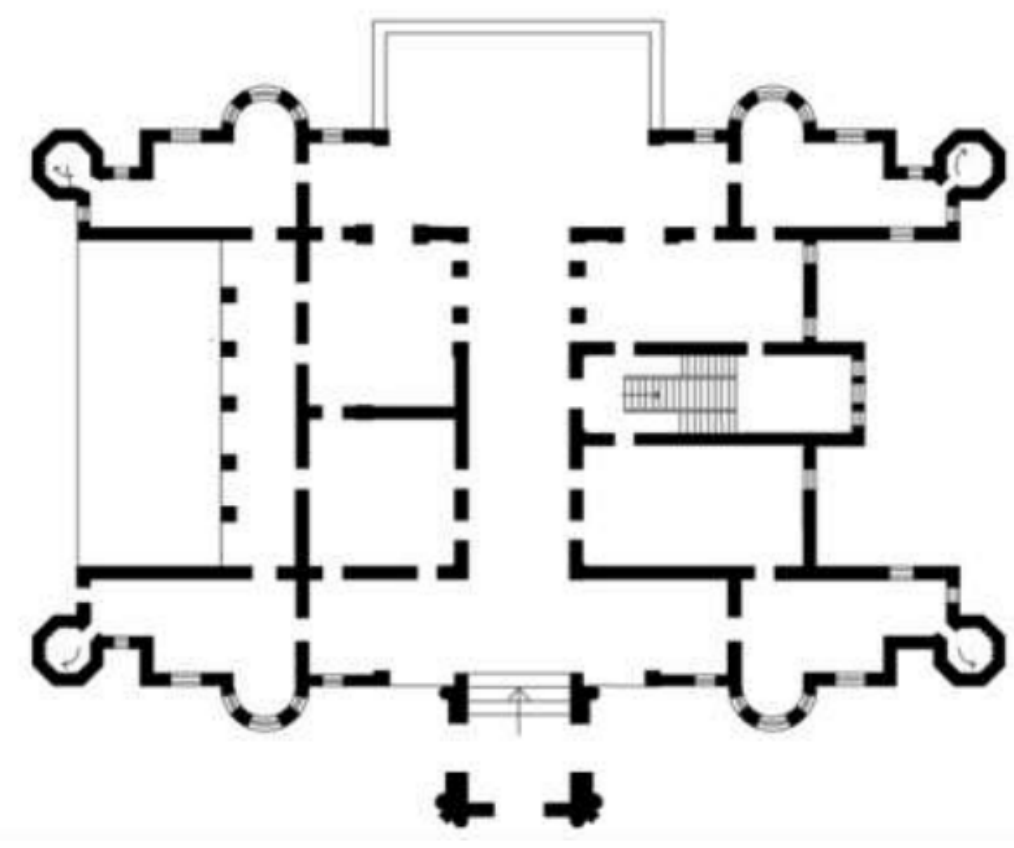

Figure 19 Plan of Rizwan

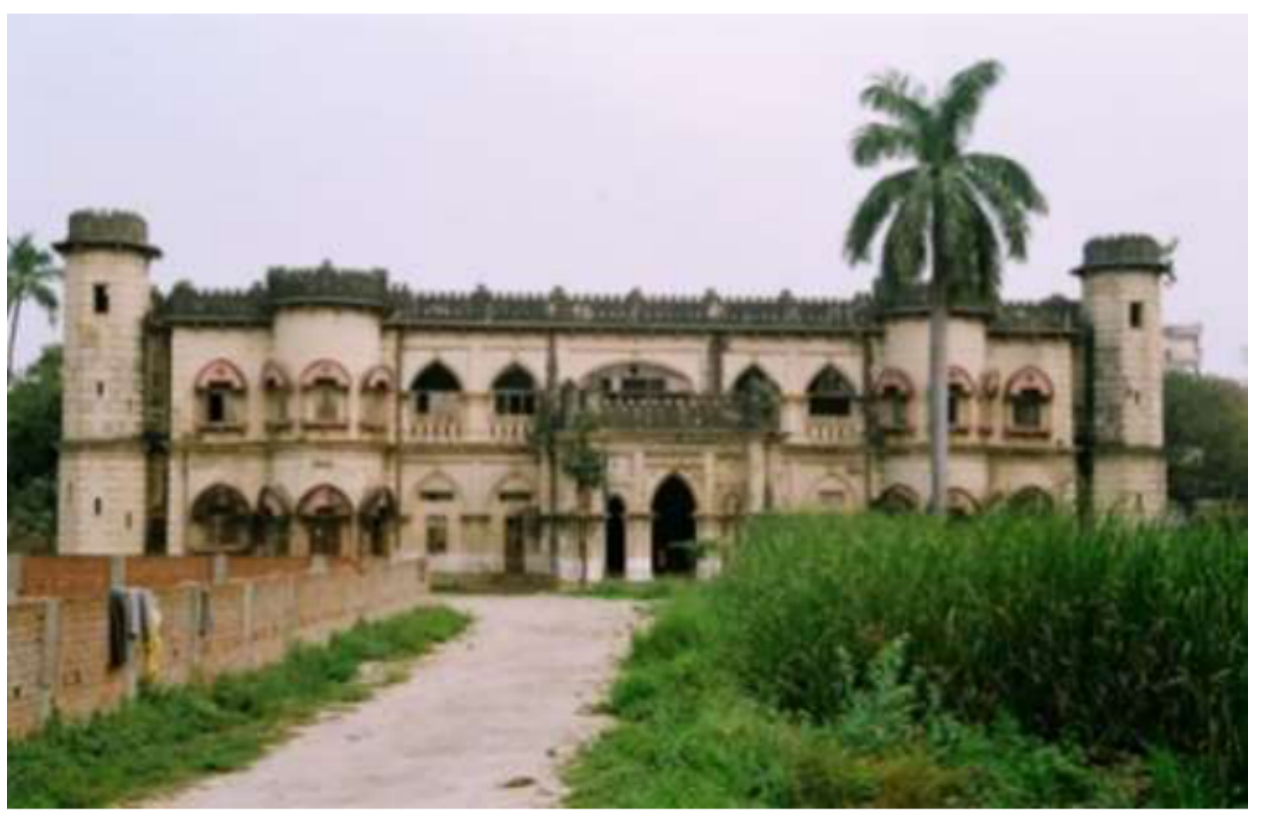

Figure 20 Rizwan

On the west of the Fraser road is Gardiner road where Sir Sultan Ahmad another leading practitioner in the High court built his havelli- 'Sultan Palace 'in 1926-28. It is a magnificent architectural piece drawing from indigenous style in the plan and Mughal architecture in the elevation. It has two parts connected through a corridor. The front structure caters exclusively to the male members where they would receive the guests and maintain their offices, while the rear structure with a courtyard plan was exclusively for the female members.

The European influence on the plan is limited to the front of the house only which includes a lavish drawing room with wooden panelling, fireplace, decorations on walls and ceilings and mouldings in Plaster of Paris. The ceiling has beautiful embossed design painted with powder of gold. The structure has wide verandah in front and on the sides. The main 
entrance leads directly to the marble majestic staircase. The rooms in the front block have teak wall panelling. In contrast, the ladies block behind has the indigenous plan with rooms around the central courtyard. The important rooms in this block have beautiful paintings done on the ceiling.

All these houses were set in the middle of an extensive campus with two gates in the front from which driveways led to the centrally positioned porticos. The area enclosed between the driveway and the outer boundary was developed into beautiful gardens, a concept borrowed from European.

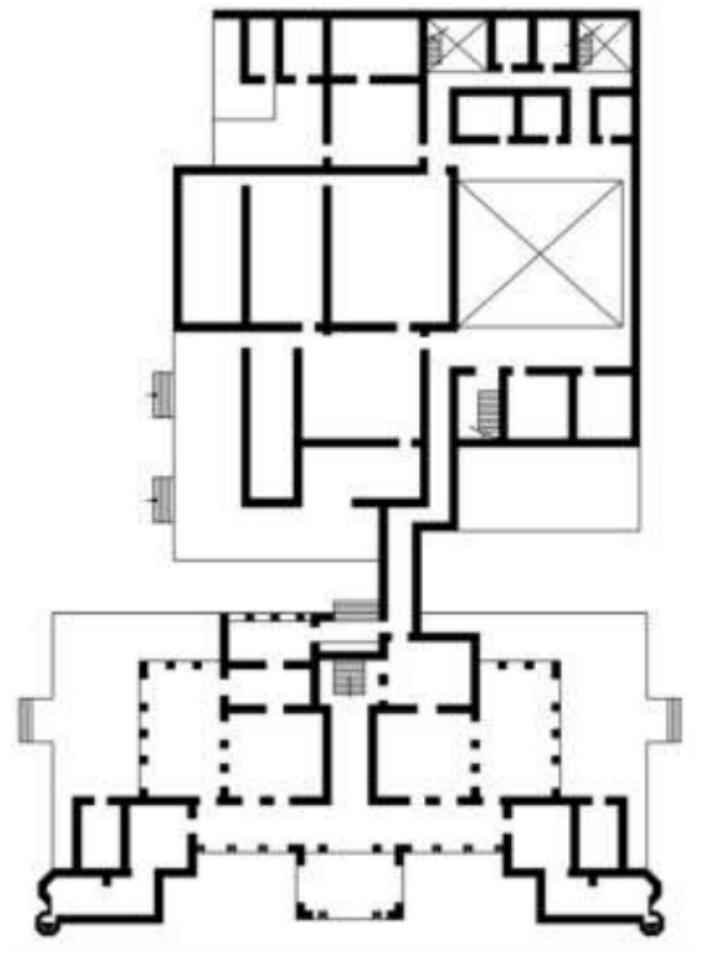

Figure 21 Plan of Sultan Palace

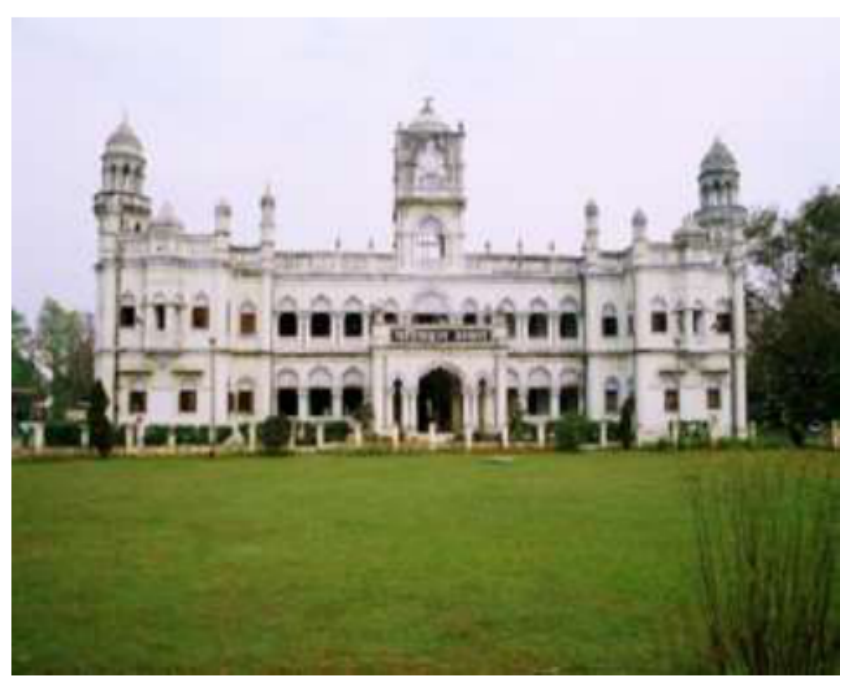

Figure 22 Sultan Palace

\subsection{Planning of the area linking Bankipore to New Patna}

Positioned between two planned areas, this area is also an extension of their basic planning. The roads are wide and open. The quarters of the judiciary are laid as per grid plan and the area is full of greenery. The quarters are double storied with front verandah and portico while the rooms are built around a central courtyard. The private houses are all big in scale and majestic in conception. The area is well laid with wide road and spacious planning. 


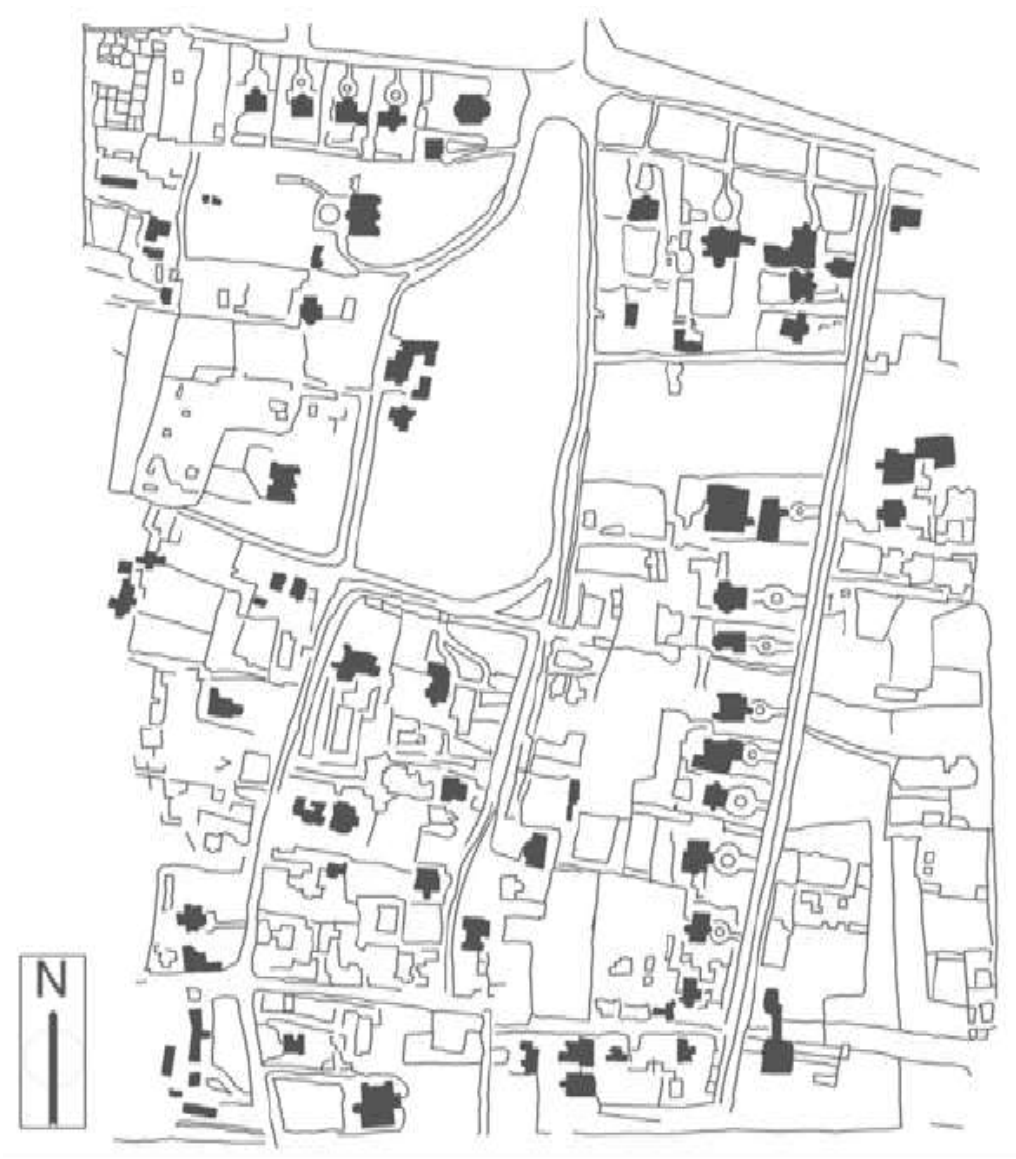

Figure 23 Map of area linking Bankipore to New Patna

\subsection{Architecture of the area between old city and Bankipore}

The Bengalis having acquired English education were brought by the English to Patna to man administrative posts in Patna [6].This happened majorly towards the end of the nineteenth century. They settled towards the south of the Ashok Rajpath in the area between the old city and Bankipore which was already growing as a transition between them. With their residences came another style of architecture. This was a small variation from the native houses but had intricate detailing in their elevation. This did not necessarily change the layout of the areas but it did have its effect on the image of the city. The intricate detailing in the railings, parapet or elements of beautification contributed towards beautification of the streets.

\subsection{Planning of the area between old city and Bankipore}

Since this area lies between the heavily built old city and the well planned open spaced Bankipore its layout shows a transition between the two. It is comparatively less congested as compared to Old city but by far crowded in comparison to Bankipore. It is more of an extension of old city with little better ambience in terms of planning and road width. Residential architecture after freedom in 1947

The area south of this linear city was further developed after India gained independence in 1947. The Architecture developed after 1947 was an amalgamation of various influences that the city had been receiving in past three hundred years. This slowly progressed towards modern architecture; modern materials and finally high rise apartment culture came to the city in 1980s which continues to be the present focus of the city dwellers. Their design in the city hardly provided common spaces. Residential architecture drew from what existed in the city 
till then but the great detailing which was apparent before 1947 slowly got simplified and remarkable examples got greatly limited.

\section{CONCLUSION}

The evolution of the city in the past few centuries has had varied influences. The indigenous culture of the place was characterized by the strong bonding and connects among the city dwellers. There seemed to be no role of dividing forces, be it between the different caste, creed or religion or be it between different strata of the society. In olden times when external influences were negligible or none, families in each mohalla were closely knit and all lived together as an extended family irrespective of caste, creed or religion. This was the strength of the local culture as there was unity in diversity.

As the city received external influence the architecture and planning introduced into the city supported the concept of distance between different strata or backgrounds. It also introduced a spacious planning which developed towards being grand in New Patna area. Architecture also became a mean of showing power and wealth. When this architecture influenced the houses of the native of the city, the culture where the entire neighbourhood lived as a closely knit family underwent a change. The type of relationship that the natives had with each other in the neighbourhood, slowly started changing from informal to formal in nature. With increased distances between houses, the day to day association of the people with each other for all life matters slowly lessened. This also affected the other requirements of the society. More formal public structures started being built. The concept of hotels, restaurants, party halls started developing. The same formal layout was further developed in the residential architecture of "New Patna" developed at the beginning of the twentieth century.

The compactness of the residences lessened the interaction between individuals and introduction of the concept of urban planning divided areas into formal and informal. This concept slowly crept into relations, which also got divided into formal and informal. The concept of compact planning slowly lessened the understanding of role of open spaces and in the race of time the later developed areas got heavily built with lack of open spaces. This has resulted in stress and immense pressure in modern life. The growing value of land, its immense demand and the available option of compact units has stolen the relaxed attitude and healthy living from the city dwellers.

Conserving the historic parts of the city will help conserve the indigenous culture which is interwoven with the city's architecture and planning.

Architecture entails and displays the values of culture accordingly it can be considered to be the identity element in the cultural sector. Since human society draws inspiration from what they see around, the role of architectural heritage around becomes profound in maintaining the culture of the city.

\section{REFERENCES}

[1] Report, Vancouver Heritage Foundation, Conserving Heritage Buildings in a green and growing Vancouver, pp. 2, 2011.

[2] King, Anthony. D., Colonial Urban Development, Culture, Social Power and Environment, Department of Sociology and Building Technology, Brunel University, London, Henley and Boston.

[3] Qeyammuddin, Ahmad (Ed), Patna through the ages-Glimpses of History, Society and Economy, 1st edition, Janaki Prakashan, Patna, pp.1, 1988. 
[4] Surendra Gopal,Patna in the Ninteenth Century (a socio-cultural profile) Ghantal Printing Works, Calcutta, 1982

[5] Ahmad Qeyammuddin (Ed),Patna through the ages-Glimpses of History, Society and Economy, 1st edition, Janaki Prakashan, Patna,1988, pg 60

[6] Surendra Gopal,Patna in the Ninteenth Century (a socio-cultural profile) Ghantal Printing Works, Calcutta, 1982, Pg 29

[7] Sinha, Kamini., Historic Evolution of Patna, Journal of Khuda Bakhsh Library, No. 140, 2005, Pg 44.

[8] V. Kokila, A Cross-Cultural Study on Individualism and Collectivism among Indian People, Journal of Management, 5(4), 2018, pp. 191-202.

[9] B.A. Adewale, A.A. Oluwatayo, O.U. Uwakonye and A.B. Ogunkoya, Shortfalls of Specification Writing In Nigerian Architectural Practice, International Journal of Civil Engineering and Technology, 9(7), 2018, pp. 497-506.

[10] Houlton, Sir John.,Bihar The Heart of India, Orient Longman, Calcutta, 1949, pp. 10-15

[11] Rana Mazin Mahdi, Enas Salim Abdul-Ahhad, Hussam Jabbar, Modernization of Architectural Heritage (Applied Study of Heritage Islamic Architectural Elements in Iraq). International Journal of Architecture (IJA), 3(2), 2017, pp. 10-17

[12] O’Malley, L.S.S., Bihar and Orissa District Gazetter - Patna, 1924, pp 143

[13] Hitha Paulson and Dr. Rajesh R, Nvram Applications in the Architectural Revolutions of Main Memory Implementation - A Memristor Walkthrough, Volume 5, Issue 12, December (2014), pp. 129-133

[14] Gopal, Surendra, Patna in the Ninteenth Century (a socio-cultural profile) 1st ed, Ghantal Printing Works, Calcutta,pp. ,1982.

[15] Waleed Khaled Yasser, Happiness in Architecture. International Journal of Architecture (IJA), 4(2), 2018, pp 1-10.

[16] Sourav Mohanty, Seismic Retrofit: Architectural Approach for Earthquake Prone Areas. International Journal of Civil Engineering and Technology, 9(3), 2018, pp. 339-346. 